九州大学学術情報リポジトリ

Kyushu University Institutional Repository

\title{
Rationalization of Public Forest Management Using Multiple Regression Analysis: Focused on Jeonbuk Province in Korea
}

Lee, Sang Hyun

Faculty of Forest Science, Chonbuk National University

Shin, Choung Ho

Department of Environment and forest, Muju County office

Kim Hyu

Faculty of Forest Science, Chonbuk National University

Choi, Soo Im

Korea Forest Research Institute

他

https://doi.org/10.5109/10107

出版情報: 九州大学大学院農学研究院紀要. 53 (1)，pp. 309-314，2008-02-28. Faculty of Agriculture, Kyushu University

バージョン :

権利関係 : 


\title{
Rationalization of Public Forest Management Using Multiple Regression Analysis - Focused on Jeonbuk Province in Korea -
}

\author{
Sang Hyun LEE ${ }^{1 *}$, Choung Ho SHIN ${ }^{2}$, Hyun KIM', \\ Soo Im $\mathrm{CHOI}^{3}$ and Katsuhisa KOHROKI \\ Laboratory of Forest Policy, Division of Forest Environment and Management Sciences, \\ Department of Forest and Forest Products Sciences, Faculty of Agriculture, \\ Kyushu University, Fukuoka 812-8581, Japan \\ (Received October 31, 2007 and accepted November 30, 2007)
}

\begin{abstract}
This study was performed regression and statistical analyses for the questionnaires provided to the forest officials and forest management guiding members to provide effective plan of public forest management. The survey was conducted during the 4 months in 2006 involving 169 forest officials and forest management guiding members working in Jeonbuk province. Among the forest operation for public forest, conservation of forest ecological system was found to be the most highly affecting work through the regression analysis and recreational forest and green tourism was the operation that is currently carried out appropriately. Forest tendering operation was selected as the prime work to be performed considering the current financial situation of local government, and recreational forest and green tourism operation was selected as the project of future public forest. This study could be used to build more systematic and circumstantial public forest management activation plans that should be found to meet the social demand on public forest.
\end{abstract}

\section{INTRODUCTION}

Approximately, 6,400,301 ha of forest in Korea takes up $64 \%$ of total national territory $(9,961,737 \mathrm{ha})$, which is comprised by $1,470,035$ ha of national forest, 489,112 ha of public forest, and 4,441,154 ha of private forest (Korea Forest Service, 2005). However, the forest areas with the highest possibility of potential supply for the land demand was increased in industries and other social sectors caused by rapid industrialization and civilization continuously have reduced their size since 1961 (Youn, 1994).

Moreover, among the 4,441,154 ha of private forest that takes up $64 \%$ of overall forest areas, the $53 \%$ of forest areas $(2,259,800$ ha) are registered by non-resident forest owners who intend to own them with the purpose of property maintenance, graveyard acquisition and real estate venture. Hence, such aspects contradict to the conditions for reasonable forest management.

In addition, the public forest that takes up $8 \%$ of total forest areas was originally transferred with free of charge from national forest (Lee, 1994) and its original purposes are to conduct exemplary forest management to be a standardized model in private forest management and to relieve tax payers' burden through securing lumber revenue along with the goal to improve public welfare by intensifying the function of public interest. Although the public forest has very important meaning speculating such management purpose, the management of it is difficult due to its scattered distribution in many areas unlike to that of national forest and financial status

\footnotetext{
Faculty of Forest Science, Chonbuk National University, Chonju, 561-756, Korea

Department of Environment and Forest, Muju County Office, Muju, 568-800, Kore

Korea Forest Research Institute, Seoul, 130-712, Korea

* Corresponding author (E-mail: leesh@chonbuk.ac.kr)
}

and lack of willingness of local governments after the introduction of local government system which made the management status to be unsatisfactory one (Park et al., 2003).

Simultaneously with the problems stated in above, the geological problem of Korean forest or the characteristics of the forest to exhibit a long term forest production is under difficult circumstance, but the increasing population recognizing various functions of forest within the sustainable forest management paradigm and the growing perspectives of considering forest as a major environmental resource could be the opportunities to overcome many conflicts in such forest.

In reviewing the typical studies on public forest in Korea, the study on the rationalization of public forest management using the forest management planning report and related data for provincial forest of Gangwon province and public forest of Taebaek city (Kim, 1992) and the study on the rationalized public forest management based on the forest management planning report for the public forest of Jeonbuk province (Lee, 1994) have been published. But no circumstantial analysis study has been conducted regard on public forest management subjected forest officials and forest management guiding members who have many substantial relationship on public forest management.

This study conducted statistical regression analyses for the questionnaires provided to the forest officials of Jeonbuk province and forest management guiding members to estimate the effect of each essential operation by measuring the degree of importance and performance of it in public forest management. In addition, the analysis of highlight project in the future and the prime operation which should be performed for the public forest were also taken. Therefore, this study was carried out to achieve more rationalized circumstantial public forest management that can provide circumstantially useful 
information in the management of public forest.

\section{METHODS OF STUDY}

\section{Contents of the study}

This study conducted statistical analyses for the survey after categorizing the management operation of pubic forest into following 8 categories of afforestation, forest tending, forest road, mechanization, short term revenue source development, recreational forest and green tourism, prevention of forest disaster, and conservation of forest ecological system that are essential for sustainable forest management. In addition, it also analyzed primary public forest operation should be conducted and the projects that will be spotlighted in the future.

\section{Methods}

Surveying

Survey was made to the forest officials and the guiding members of forest management of Jeonbuk province who take in charge of substantial projects in public forest management. The survey included the importance of public forest, performance, the foremost public forest operation to be conducted, and promising future public forest projects. Each questionnaire was distributed by e-mail to city and county officials and to guiding members of forest management, and total 169 returned questionnaires was analyzed for the study. The reference review and related statistical survey were conducted from October, 2005 to July, 2006, and the survey was conducted for 4 months from July to October, 2006.

Methods of data processing

SPSS V.12.0 program was used to conduct the frequency analyses for general characteristics of survey subjects in the questionnaire, and frequency analysis and technical statistics were conducted for the foremost public forest operation to be conducted, and future promising public forest projects. In addition, the survey results were tested to prove the reliability of the ques- tionnaires data on the importance and performance of the forest operation, and multiple regression analysis was conducted to find the degree of forest operation contribution on the importance and performance of public forest.

\section{RESULTS AND DISCUSSION}

\section{General status}

Current status of public forest in Jeonbuk province

The land size of Jeonbuk province is $805,269 \mathrm{ha}$, and the forest size is 449,582 ha which takes up $7 \%$ of total forest areas in Korea. This is the $7^{\text {th }}$ largest areas among 16 cities and provinces in Korea. In addition, the 55.8\% of land size is occupied by forest, which shows the relatively large forest occupation rate compared to other land usage (Table 1).

Looking at the ownership of the forest land in Jeonbuk province, national forest, public forest and private forest takes up 81,368 ha (18.1\%), 28,839 ha (6.4\%) and 339,375 ha $(75.5 \%)$, respectively.

Such ownership trend of forest distribution reveals that large portion is private forest compared to the nation's forest land ownership ratio of private forest (approximately 6.5\%), but smaller in national forest (approximately 4.9\%) and public forest (approximately $1.6 \%)$.

Public forest operation status in each city and county

Seeing the operation status of public forest in Jeonbuk province for the last 5 years (2002 2006), the forest fostering project which is a main issue for the sustainable forest management in Korea was strategically supported through the operation of natural forest tending (1230.92 ha), silviculture thinning (543.47 ha), young tree tending (41.1 ha) and weeding (11.14 ha) as shows in Table 2.

Muju county performed the operation size of 565 ha in recent 5 years which carried out the largest forest operation more than 100 ha annually. The order of per-

Table 1. Forest land areas by ownership

(Unit: ha)

\begin{tabular}{|c|c|c|c|c|c|}
\hline Region & Areas & Forest Land & National Forest & Public Forest & Private Forest \\
\hline Total & $9,961,737$ & $6,400,301$ & $1,470,035$ & 489,112 & $4,441,154$ \\
\hline Seoul City & 60,539 & 15,750 & 6,433 & 1,514 & 7,803 \\
\hline Busan City & 76,339 & 36,484 & 5,498 & 2,041 & 28,945 \\
\hline Daegu City & 88,558 & 49,444 & 1,235 & 2,800 & 45,409 \\
\hline Incheon City & 99,278 & 40,620 & 4,938 & 1,864 & 33,818 \\
\hline Gwangju City & 50,134 & 20,044 & 1,882 & 824 & 17,338 \\
\hline Daejeon City & 53,958 & 30,479 & 3,948 & 1,631 & 24,900 \\
\hline Ulsan City & 105,674 & 69,438 & 5,580 & 2,305 & 61,553 \\
\hline Gyeongi Province & $1,013,218$ & 534,599 & 93,334 & 41,174 & 400,091 \\
\hline Gangwon Province & $1,661,239$ & $1,371,123$ & 758,754 & 101,282 & 511,087 \\
\hline Chungbuk Province & 743,177 & 498,251 & 79,453 & 82,316 & 336,482 \\
\hline Chungnam Province & 859,848 & 441,544 & 27,487 & 21,233 & 392,824 \\
\hline Jeonbuk Province & 805,269 & 449,582 & 81,368 & 28,839 & 339,375 \\
\hline Jeonnam Province & $1,205,186$ & 696,400 & 69,500 & 31,132 & 595,768 \\
\hline Gyeongbuk Province & $1,902,619$ & $1,346,515$ & 240,560 & 115,666 & 990,289 \\
\hline Gyeongnam Province & $1,051,881$ & 708,769 & 59,979 & 48,064 & 600,726 \\
\hline Jeju Province & 184,820 & 91,259 & 30,086 & 6,427 & 54,746 \\
\hline
\end{tabular}

Source: Statistical yearbook of forestry (Korea Forest Service, 2005) 
Table 2. The operation status of public forest during the recent 5 years

\begin{tabular}{|c|c|c|c|c|c|c|c|c|c|}
\hline Region & $\begin{array}{c}\mathrm{A} \\
\text { (site) }\end{array}$ & $\begin{array}{c}\text { B } \\
\text { (ha) }\end{array}$ & $\begin{array}{c}\text { C } \\
\text { (ha) }\end{array}$ & $\begin{array}{c}\text { D } \\
\text { (ha) }\end{array}$ & $\begin{array}{c}\mathrm{E} \\
\text { (ha) }\end{array}$ & $\begin{array}{c}\mathrm{F} \\
\text { (ha) }\end{array}$ & $\begin{array}{c}\text { G } \\
\text { (ha) }\end{array}$ & $\begin{array}{c}\mathrm{H} \\
(\mathrm{Km})\end{array}$ & Others \\
\hline Gunsan & & 2.14 & 2.14 & 0.1 & 22.47 & 121.92 & & & \\
\hline Namwon & 2 & & & & 86 & 100 & & 2 & 11 tree injection \\
\hline Muju & & 5 & 5 & 35 & 203 & 317 & & & 17 \\
\hline Buan & & & & 6 & & 370 & & & 9 \\
\hline Sunchang & & & & & & 116 & & & \\
\hline Wanju & 2 & & & & & 10 & & & 30 \\
\hline Iksan & & & & & 82 & & & & \\
\hline Imsil & 1 & 5 & 4 & & 150 & 196 & & & 3 \\
\hline Jangsu & 2 & & & & & & & & \\
\hline Jeongeup & & & & & & & & & 2 \\
\hline Jeonju & & & & & & & & & \\
\hline Gimje & & & & & & & & & \\
\hline $\begin{array}{l}\text { Gochang } \\
\text { Jinan }\end{array}$ & & & & & & & & & \\
\hline Total & 7 & 12.14 & 11.14 & 41.1 & 543.47 & $1,230.92$ & & 2 & 72 \\
\hline
\end{tabular}

* A: Recreational forest, B: Afforestation, C: Weeding, D: Young tree tending, E: Silviculture thinning,

F: Natural forest tending, G: Final cutting, and H: Forest road.

formed operation was mainly focused on forest fostering projects by assigning the works on natural forest tending (317 ha), silviculture thinning (203 ha), young tree tending (35 ha), and afforestation and weeding ( 5 ha).

However, the Jinan which takes up $21.7 \%$ of total public forest areas of Jeonbuk province, Gochang $(0.7 \%)$, Gimjae (0.5\%) counties and Jeonju city (0.3\%) did not act on public forest operation for the last 5 years without providing any investment on public forest. This phenomenon could be interpreted as worsening investment circumstance on forest investment due to financial status of local governments in cities and counties of Jeonbuk province.

The values of public interest of public forest owned by Jeonbuk province could be estimated as $\$ 264.4$ Million (Jangsu county, 2005), and this provides very large portion of interest let alone the previously stated economical value, but these values are substantially unrecognized causing lack of investment. This is the circumstance that contradicts to the establishment purpose of public forest which should be the exemplary case in private forest management. So, the change of conception and recognition enlightening on public forest should be necessary.

\section{Analysis of respondents}

The respondents of the survey were total 169 people, and 70 people of them were mostly ranged in 30 39 years old $(41.4 \%)$, followed by 62 people in $40 \sim 49$ years old (36.7\%), 20 people in more than 50 years old (11.8\%) and 17 people were less than 30 years old (10.1\%). The 57 respondents (33.7\%) had careers ranging from 11 years to 20 years by taking up the largest proportion, and most of them were estimated to have professional knowledge in the forest operation. Also, 52 people (30.8\%) had less than 5 years of career, 35 people $(20.7 \%)$ had more than 20 years of career, and 25 people (14.8\%) had careers between 5 and 10 years (Table 3).
Table 3. Respondents' characteristics of questionnaire

\begin{tabular}{|c|c|c|c|}
\hline \multicolumn{2}{|r|}{ lassification } & $\begin{array}{c}\text { Frequency } \\
\text { (No.) }\end{array}$ & $\begin{array}{c}\text { Percentage } \\
\text { (\%) }\end{array}$ \\
\hline \multirow{5}{*}{ Age } & Below 30 years & 17 & 10.1 \\
\hline & 30 39 years & 70 & 41.4 \\
\hline & 40 49 years & 62 & 36.7 \\
\hline & Above 50 years & 20 & 11.8 \\
\hline & Total & 169 & 100.0 \\
\hline \multirow{5}{*}{ Career } & Less than 5 years & 52 & 30.8 \\
\hline & $5 \sim 10$ years & 25 & 14.8 \\
\hline & $11 \sim 20$ years & 57 & 33.7 \\
\hline & More than 20 years & 35 & 20.7 \\
\hline & Total & 169 & 100.0 \\
\hline
\end{tabular}

\section{Regression analysis of importance and perform- ance in forest operation}

Reliability analysis

In order to confirm whether the data of importance and performance of the forest operation acquired through the survey could be reliable or not, the Cronbach's $\alpha$ value was used. The Cronbach's $\alpha$ values for the importance and performance of the forest operation were 0.807 and 0.876 , respectively. Therefore, the data was confirmed to be reliable (Table 4).

Regression analysis of importance

The importance of public forest operation was categorized by following 8 sectors of afforestation (A), forest tending (B), forest road (C), mechanization (D), short term revenue source development $(\mathrm{E})$, recreational forest and green tourism (F), prevention of forest disaster (G) and conservation of forest ecological system $(\mathrm{H})$, which could be regard as important forest works in the sustainable forest management, and statistical analysis was conducted using 5 points scale. The above stated 8 categories were assigned as independent variables and the importance of forest operation was assigned as a dependent variable, and the multiple regression analysis was performed using the stepwise analysis method (Jung 
Table 4. Reliability analysis for each attribute

\begin{tabular}{|c|c|c|c|c|}
\hline Attributes* & & Mean & Std. Dev. & $\begin{array}{l}\text { Alpha if } \\
\text { Item Deleted }\end{array}$ \\
\hline \multirow{8}{*}{ Importance } & A & 3.69 & 0.900 & 0.788 \\
\hline & B & 4.27 & 0.670 & 0.795 \\
\hline & $\mathrm{C}$ & 4.00 & 0.756 & 0.787 \\
\hline & $\mathrm{D}$ & 3.85 & 0.828 & 0.768 \\
\hline & $\mathrm{E}$ & 3.85 & 0.904 & 0.789 \\
\hline & $\mathrm{F}$ & 4.24 & 0.760 & 0.783 \\
\hline & G & 4.11 & 0.743 & 0.776 \\
\hline & $\mathrm{H}$ & 4.23 & 0.732 & 0.796 \\
\hline \multicolumn{5}{|c|}{$\alpha=0.807, N=169$} \\
\hline \multirow{8}{*}{ Performance } & A & 3.05 & 0.885 & 0.853 \\
\hline & B & 3.28 & 0.888 & 0.855 \\
\hline & $\mathrm{C}$ & 3.11 & 0.880 & 0.859 \\
\hline & $\mathrm{D}$ & 2.49 & 0.874 & 0.864 \\
\hline & $\mathrm{E}$ & 2.49 & 0.832 & 0.870 \\
\hline & $\mathrm{F}$ & 2.92 & 0.866 & 0.863 \\
\hline & G & 3.14 & 0.895 & 0.853 \\
\hline & $\mathrm{H}$ & 3.14 & 0.882 & 0.867 \\
\hline \multicolumn{5}{|c|}{$\alpha=0.876, N=169$} \\
\hline $\begin{array}{l}* \text { A: Affore } \\
\text { Mechanizati } \\
\text { F: Recreatio } \\
\text { est disaster, }\end{array}$ & & $\begin{array}{l}\text { orest } \\
\text { pment } \\
\text { greer } \\
\text { rvation }\end{array}$ & $\begin{array}{l}\text { ing, C: } \\
\text { ort erm s } \\
\text { ism, G: P } \\
\text { rest ecolc }\end{array}$ & $\begin{array}{l}\text { rest road, D } \\
\text { rce of income, } \\
\text { vention of for- } \\
\text { cal system. }\end{array}$ \\
\hline
\end{tabular}

et al., 2002) to observe the effect of several independent variables to the dependent variable. The results of the analysis are summarized in Table 5.

Since the properties of forest tending (B) and prevention of forest disaster $(G)$ showed to be statistically insignificant at the $95 \%$ significant level $(\alpha=0.05)$, they were turned out to have no effect as the explanatory variables of multiple regression analysis regard on the importance of the public forest operation. The importance of public forest operation represented as in TI could be expressed as the regression model (Equation (1)). The $R^{2}$ value which indicates the degree of explanation of the model showed very high value of 0.964 indicating that the equation (1) should be appropriate in expressing the importance of public forest operation as a dependent variable.

$\mathrm{TI}=0.293+0.17 \mathrm{D}+0.14 \mathrm{~F}+0.14 \mathrm{~A}+0.2 \mathrm{H}$
$+0.134 \mathrm{E}+0.153 \mathrm{C}$

Standardized coefficients $(\beta)$ of regression of each operation which have effects on the importance of public forest works showed a similar value ranging from 0.20 to 0.28 , which represents almost same effect of each operation. The regression model was relatively highly affected by conservation of forest ecological system $(\mathrm{H})$ followed by mechanization (D), afforestation (A), short term revenue source development (E), recreational forest and green tourism (F), and by forest road (C). Hence, the aspect of forest ecological system and environmental factors were thought to be represented in the circumstance of sustainable forest management paradigm. In addition, the mechanization and forest road facilitations which could be regarded as the basic facilities for the public forest management activation were pointed out as the second and the third important variables, respectively.

The result of afforestation as the important variable in the public forest management could be interpreted as the result of pursuing the change of afforestation pattern to increase revenue through economically beneficial afforestation and water conservation afforestation after the deforestation with species regeneration of the previously planted larch and rigida fine trees which reached their rotation ages. The recreational forest and green tourism and the development of short term revenue source works were turned out to be the operation that can make direct revenue in public forest which could be attractive in local governments where intended to increase revenue.

Regression analysis of performance

As it has been established in the regression analysis of importance of the public forest operation, the performance of public forest operation was comprised by 8 categories, and statistical analysis was conducted using 5 points scale. Using the same method as in the test of importance, the 8 properties were set as independent variables, and the performance of public forest operation was set as a dependent variable to conduct the stepwise multiple regression analysis. The results of the analysis are summarized in Table 6.

The conservation of forest ecological system $(\mathrm{H})$ and

Table 5. Multiple regression analysis table for Importance

\begin{tabular}{|c|c|c|c|c|c|c|c|}
\hline \multirow{2}{*}{ Attributes* } & \multicolumn{2}{|c|}{$\begin{array}{l}\text { Unstandardized } \\
\text { Coefficients }\end{array}$} & $\begin{array}{c}\text { Standardized } \\
\text { Coefficients }\end{array}$ & \multirow[t]{2}{*}{$\mathrm{t}$} & \multirow[t]{2}{*}{ Sig. } & \multirow[t]{2}{*}{$\mathrm{R}$} & \multirow[t]{2}{*}{$\mathrm{R}^{2}$} \\
\hline & B & Std. Error & $\beta$ & & & & \\
\hline (Constant) & 0.293 & 0.060 & & 4.843 & 0.00 & & \\
\hline D & 0.170 & 0.012 & 0.273 & 13.875 & 0.00 & & \\
\hline F & 0.140 & 0.013 & 0.206 & 10.868 & 0.00 & & \\
\hline A & 0.140 & 0.011 & 0.244 & 13.301 & 0.00 & 0.982 & 0.964 \\
\hline $\mathrm{H}$ & 0.200 & 0.012 & 0.284 & 16.375 & 0.00 & & \\
\hline $\mathrm{E}$ & 0.134 & 0.010 & 0.235 & 13.094 & 0.00 & & \\
\hline $\mathrm{C}$ & 0.153 & 0.013 & 0.224 & 11.871 & 0.00 & & \\
\hline
\end{tabular}

*A: Afforestation, C: Forest road, D: Mechanization, E: Development of short term source of income,

F: Recreational forest and green tourism, and H: Conservation of forest ecological system. 
Table 6. Multiple regression analysis table for Performance

\begin{tabular}{|c|c|c|c|c|c|c|c|}
\hline \multirow[t]{2}{*}{ Attributes* } & \multicolumn{2}{|c|}{$\begin{array}{l}\text { Unstandardized } \\
\text { Coefficients }\end{array}$} & $\begin{array}{c}\text { Standardized } \\
\text { Coefficients }\end{array}$ & \multirow[t]{2}{*}{$\mathrm{t}$} & \multirow[t]{2}{*}{ Sig. } & \multirow[t]{2}{*}{$\mathrm{R}$} & \multirow[t]{2}{*}{$\mathrm{R}^{2}$} \\
\hline & B & Std. Error & $\beta$ & & & & \\
\hline (Constant) & 0.134 & 0.036 & & 3.689 & 0.00 & & \\
\hline G & 0.177 & 0.012 & 0.248 & 14.529 & 0.00 & & \\
\hline A & 0.145 & 0.013 & 0.200 & 10.730 & 0.00 & & \\
\hline $\mathrm{F}$ & 0.193 & 0.011 & 0.261 & 17.694 & 0.00 & 0.988 & 0.976 \\
\hline $\mathrm{D}$ & 0.175 & 0.011 & 0.239 & 15.789 & 0.00 & & \\
\hline B & 0.139 & 0.014 & 0.192 & 10.256 & 0.00 & & \\
\hline $\mathrm{C}$ & 0.118 & 0.012 & 0.162 & 9.491 & 0.00 & & \\
\hline
\end{tabular}

*A: Afforestation, B: Forest tending, and C: Forest road, D: Mechanization, F: Recreational forest and green tourism, and G: Prevention of forest disaster.

short term revenue source development (E) did not show statistical significance at the 95\% significant level $(\alpha=0.05)$ indicating the no effect on the multiple regression model for the performance of the public forest operation at the test of stepwise analysis method. The multiple regression model to explain the performance of public forest (TP) could be represented as the equation (2).

$$
\begin{aligned}
\mathrm{TP}= & 0.134+0.177 \mathrm{G}+0.145 \mathrm{~A}+0.193 \mathrm{~F} \\
& +0.175 \mathrm{D}+0.139 \mathrm{~B}+0.118 \mathrm{C}
\end{aligned}
$$

The $\mathrm{R}^{2}$ value that explains the explanation of the model was 0.976 which could be judged to be appropriate in the performance test of public forest operation.

Based upon the analysis results, the performance test of public forest operation was relatively highly affected by recreational forest and green tourism (F) that had the standardized coefficient of regression $(\beta)$ of 0.261 that was followed by prevention of forest disaster (G), mechanization (D), and afforestation (A).

However, forest tending (B) and forest road (C) turned out to have rather mere effect on the model by showing the standardized coefficient of regression of 0.192 and 0.162 , respectively. The variable of recreational forest and green tourism that showed the highest effect on the performance model of public forest management was affected by recreational forest that is the only available method to have revenue in public forest, and the variable of preventing forest disaster might indicate the public interest of forest.

\section{The prime public forest operation to be conducted.}

The investigation was performed about prime public forest operation to be conducted to secure the investment efficiency considering the current circumstance of limited investment environments of public forest. Among the 8 public forest operation, the 3 most highly responded answers were analyzed through the frequency test, and the first operation was found to be the forest tending and the second work was the recreational forest and green tourism, and the third operation was also found to be the recreational forest and green tourism as shown in Table 7.

The above investigation result was acquired from the forest officials and forest management guiding mem-
Table 7. Primary forest operation for public forest develop-

\begin{tabular}{|c|c|c|}
\hline Attributes* & Frequency & Percent \\
\hline \multicolumn{3}{|c|}{ First order } \\
\hline $\mathrm{A}$ & 14 & 7.7 \\
\hline $\mathrm{B}$ & 46 & 27.2 \\
\hline $\mathrm{C}$ & 17 & 10.1 \\
\hline $\mathrm{D}$ & 2 & 1.2 \\
\hline $\mathrm{E}$ & 14 & 8.3 \\
\hline $\mathrm{F}$ & 29 & 17.2 \\
\hline G & 15 & 8.9 \\
\hline $\mathrm{H}$ & 29 & 17.2 \\
\hline Missing value & 4 & 2.4 \\
\hline Total & 169 & 100.0 \\
\hline \multicolumn{3}{|c|}{ Second order } \\
\hline A & 5 & 3.0 \\
\hline B & 33 & 19.5 \\
\hline $\mathrm{C}$ & 23 & 13.6 \\
\hline D & 8 & 4.7 \\
\hline $\mathrm{E}$ & 17 & 10.1 \\
\hline $\mathrm{F}$ & 34 & 20.1 \\
\hline G & 20 & 11.8 \\
\hline $\mathrm{H}$ & 25 & 14.8 \\
\hline Missing value & 4 & 2.4 \\
\hline Total & 169 & 100.0 \\
\hline \multicolumn{3}{|c|}{ Third order } \\
\hline A & 12 & 7.1 \\
\hline B & 23 & 13.6 \\
\hline $\mathrm{C}$ & 21 & 12.4 \\
\hline $\mathrm{D}$ & 10 & 5.9 \\
\hline $\mathrm{E}$ & 15 & 8.9 \\
\hline $\mathrm{F}$ & 35 & 20.7 \\
\hline G & 19 & 11.2 \\
\hline $\mathrm{H}$ & 28 & 16.6 \\
\hline Missing value & 6 & 3.6 \\
\hline Total & 169 & 100.0 \\
\hline
\end{tabular}
ment

*A: Afforestation, B: Forest tending, C: Forest road, D: Mechanization, E: Development of short term source of income, F: Recreational forest and green tourism, G: Prevention of forest disaster, and $\mathrm{H}$ : Conservation of forest ecological system.

bers who work at the front line of forest related works. Their selection of forest tending as the currently required first operation considering the investment efficiency has a significant meaning.

Currently, forest fostering operation have been annually conducted for national and private forests, and the previous policy and works that focus on afforestation 
are about to change. At such time point, public forest is recognized as the forest that should be managed. Accordingly, public forest should have a foundation to produce high quality wood products through systematic management. Simultaneously, the value of public interest has to be intensified by means of like water conservation afforestation, and the direction of public forest management plan seems necessary to contribute to the increment of revenue of corresponding cities and counties.

\section{Future public forest projects}

Which project will be favored by public and will be the most efficient project in the public forest management was investigated. As selected variables, the following 6 variables of lumber production, production of forest by-products, recreational forest and green tourism, forest education and research projects, conservation and management of ecological system, and natural burials model forest were used for the frequency test analysis.

Recreational forest and green tourism took up the highest frequency and percentage (50.3\%) followed by conservation and management of ecological system, natural burials model forest, production of forest by-products, forest education and research projects, and lumber production as shown in Table 8.

Table 8. Primary operation highlighted in the future for public forest management

\begin{tabular}{ccc}
\hline Attributes* $^{*}$ & Frequency & Percent \\
\hline A & 3 & 1.8 \\
B & 13 & 7.7 \\
C & 85 & 50.3 \\
D & 13 & 7.7 \\
E & 37 & 21.9 \\
F & 16 & 9.5 \\
Missing value & 2 & 1.2 \\
Total & 169 & 100.0
\end{tabular}

*A: Lumber production, B: By-product production, C: Recreational forest and green tourism, D: Forest education and research project, E: Ecosystem conservation and management, and F: Natural burials model forest.

Recreational forest and green tourism (C) had the most potential to be activated for the rational utilization of public forest at the current time. So, it is judged that a local government of each city and county should refer the result in planning the public forest projects, and the second ranked conservation of forest ecological system (E) by recording $21.9 \%$ could be interpreted as the role of public forest in future generation by meeting the meaning of sustainable forest development.

In case of the third placed natural burials model forest $(F)$, the project is merely recognized by general public since the survey was conducted for the professionals who have deep relation in forest policy, and they selected it from the aspect of recognizing the necessity of forest activation using public forest to increase revenue.

\section{CONCLUSIONS}

Among the forest operation for public forest, conservation of forest ecological system was found to be the most highly affecting operation through the multiple regression analysis of importance and performance, and recreational forest and green tourism was the operation that is currently carried out appropriately.

Forest tendering operation, which was selected as the prime work to be performed considering the current financial situation of local government to the public forest, tended to well represent current forest status of Korea. Therefore, the portion of forest fostering project in public forest should be increased to comprise representative forest to meet the functional aspect of forest and to maintain the eco-environmental soundness simultaneously. In addition, the investment and management efforts should be made on the secondly selected operation of recreational forest and green tourism to have a specialized various recreational function with various landscapes and rich variety of species.

Recreational forest and green tourism work which was selected as the future public forest project seemed to be the thought of all the people, which is not only limited to the thought of forest related officials. Therefore, the efforts of providing fresh environment and recreational places have to be made to foster a sound pubic forest that can contribute to maintain and improve psychological and physical health of a human being.

Considering the importance of public forest which has its purpose of existence by conducting an exemplary forest management to be the model of private forest management along with the benefit of lowering tax payers' burden by securing the lumber revenue and to improve the pubic welfare through the increment of public interest in public forest, it is very important to deliberate management activation plans of public forest. In that sense, more systematic and circumstantial public forest management activation plans should be found to meet the social demand on public forest and to solve systematic problems of public forest.

\section{REFERENCES}

Jangsu county. 2005 Forest master plan of Jangsu county Jung, Y. C., J. H. Kang, S. H. Jeon and D. G. Beun. 2002 Statistical analysis using SPSS program

Kim, D. J. 1992 Study on the management rationalization of public forest (focused on Tae-baek city), Master's thesis, Kangwon University

Korea Forest Service. 2005 Statistical yearbook of forestry

Lee, S. H 1994 Study on the rationalization of public forest management. Master's thesis, Chonbuk National University

Park, T. S., D. C. Kim., M. W. Lee., S. S. Lee., Y. H. Lee., Y. H. Cho., S. Y. Kang., W. H. Beon and J. C. Woo 2003 Forest management. Hyangmoonsa, Korea

Youn, Y. C. 1994 Study on the effect of national forest management on the local community. Journal of Korean Forestry Society, 83(1): 38-49 